\title{
Effect of relaxin on facilitation of parturition in dairy heifers*
}

\author{
B. Bagna $\dagger$, C. Schwabe $\ddagger$ and L. L. Anderson $\dagger$ \\ $\dagger$ Department of Animal Science, Iowa State University, Ames, IA 50011, USA; and $\ddagger$ Department of \\ Biochemistry, Medical University of South Carolina, Charleston, SC 29495, USA
}

\begin{abstract}
Summary. Purified pig relaxin $(3000 \mathrm{U} / \mathrm{mg})$ was injected i.m. into pregnant Holstein dairy heifers on Day 276 or 277 to determine its effect on parturition and sequential measurements of the pelvic area, cervical dilatation, and peripheral blood-plasma concentrations of progesterone and relaxin. Treatments included phosphate-buffer saline ( $2 \mathrm{ml}$, Group $\mathrm{C}, \mathrm{N}=7$ ), relaxin once ( $1 \mathrm{mg}$, Group $1 \mathrm{R}, \mathrm{N}=7)$, and twice $(2 \mathrm{mg}$, $12 \mathrm{~h}$ apart; Group 2R, $\mathrm{N}=7$ ). Intervals (mean \pm s.e.) between the first injection of relaxin or PBS and calving were $64 \pm 17,80 \pm 19$ and $125 \pm 34 \mathrm{~h}$ for Groups $2 \mathrm{R}$, $1 \mathrm{R}$ and $\mathrm{C}$, respectively. The calving intervals were reduced in Groups $2 \mathrm{R}(P<0.01)$ and 1R $(P<0.05)$ compared with Group $C$. The incidence of dystocia was $29 \%$ ( 2 of 7 ) in Group 2R and 43\% (3 of 7) in Group 1R compared with 57\% (4 of 7) in Group C $(P<0.01)$. Body weights and ratios of males to females of the calves were similar $(P>0.05)$ between groups. Progesterone plasma concentrations decreased $(P<0.01)$ earlier in Groups $1 \mathrm{R}$ and $2 \mathrm{R}$ compared with Group $\mathrm{C}$, and this acute decrease began within $6 \mathrm{~h}$ of treatment. At $24 \mathrm{~h}$ after relaxin or PBS injection, progesterone concentrations were $2.7 \pm 1.1 \mathrm{ng} / \mathrm{ml}$ for Group $2 \mathrm{R}, 3.5 \pm 0.9 \mathrm{ng} / \mathrm{ml}$ for Group $1 \mathrm{R}$, and $6.0 \pm 0.1 \mathrm{ng} / \mathrm{ml}$ for Group C. Relaxin reached peak blood-plasma levels of $19 \pm 2.2 \mathrm{ng} / \mathrm{ml} 1 \mathrm{~h}$ after injection of relaxin, but remained unchanged, $0.3 \pm 0.01 \mathrm{ng} / \mathrm{ml}$, in Group C. Pelvic area was increased $26 \%, 22 \%$ and $14 \%$ and cervical dilatation was increased $109 \%, 76 \%$ and $53 \% 48 \mathrm{~h}$ after injection in Groups $2 \mathrm{R}, 1 \mathrm{R}$ and $\mathrm{C}$, respectively, but these responses were similar among groups at the time of parturition. We conclude that two i.m. injections of relaxin facilitated earlier calving, acutely decreased progesterone secretion, increased cervical dilatation and pelvic area expansion, and decreased the incidence of dystocia in dairy heifers.
\end{abstract}

Keywords: relaxin; parturition; progesterone; cervix; pelvic area; dystocia; dairy cattle

\section{Introduction}

Relaxin is a polypeptide hormone with a molecular weight of approximately 6000 and partial structural homology to insulin and insulin-like growth factors (Sherwood \& O'Byrne, 1974; Schwabe et al., 1976, 1977). Relaxin is produced in greatest concentrations by female reproductive tissues, particularly during pregnancy (Anderson, 1987; Sherwood, 1988). The corpus luteum of the pig is a rich source of this hormone (Anderson et al., 1973), but small concentrations of biologically active relaxin, as measured by inhibition of uterine contractility and a radioimmunoassay for pig relaxin, were found in bovine corpora lutea and the circulating blood of cattle during late pregnancy (Fields et al., 1980; Anderson et al., 1982; Musah et al., 1986b, 1987a, b, 1988). The circulating form of relaxin during its pre-partum peak release in the pig is the same as that found in

*Reprint requests to Professor L. L. Anderson 
the ovary (Felder et al., 1986; Li et al., 1989; O'Byrne et al., 1989). In contrast, circulating concentrations of immunoreactive relaxin in cattle remain consistently low, with no evidence for major release of the hormone as seen in the pig. Administration of relaxin by i.m. injection or into the cervical os induces marked changes in cervical dilatation; pelvic relaxation (Perezgrovas \& Anderson, 1982; Musah et al., 1986a, b, 1988); separation of the pubic symphysis, with interpubic ligament formation (Schwabe et al., 1978; Porter, 1979, 1984); and facilitation of parturition in animals of some species (MacLennan et al., 1980; Evans et al., 1983; Musah et al., 1986a, b; Anderson, 1987). Relaxin is involved in luteolysis during late pregnancy in cattle, affecting peripheral blood concentrations of progesterone, oestrogen, oxytocin and prostaglandin (PG) F-2 $\alpha$ (Musah et al., 1986b, 1987a, b, 1989a, b). Furthermore, relaxin has direct effects on oxytocin and progesterone secretion by cultured bovine luteal cells during different stages of gestation (Musah $e t$ al., 1990a, b).

The objectives of this study were to determine the effects of two i.m. injections of purified pig relaxin on the facilitation of parturition in dairy heifers. Part of this investigation has been presented in abstract form (Bagna et al., 1990).

\title{
Materials and Methods
}

\begin{abstract}
Animals. Holstein heifers, approaching their first calving, were used. All 21 heifers were artificially inseminated at oestrus (Day 0). The heifers were maintained in an assigned lot during early pregnancy, and at 3 weeks pre partum they were moved to a special lot (lot no. 9 at the Iowa State University Dairy Farm), where each animal received $2.72 \mathrm{~kg}$ grain mix and $4.54 \mathrm{~kg}$ corn silage per day. Free-choice grass hay and water were available at all times. The heifers were checked while feeding for signs of imminent calving. Heifers were brought into the maternity barn 5 days before expected calving, where they received the same feeding regimen. After calving, each heifer was given $4.54 \mathrm{~kg}$ corn silage plus $2 \cdot 72 \mathrm{~kg}$ grain mix daily, as well as free-choice alfalfa hay.
\end{abstract}

Experimental groups. The heifers were assigned randomly to one of three treatment groups: PBS-treated controls [Group C, $\mathrm{N}=7 ; 2 \mathrm{ml}$ phosphate-buffer saline (PBS)]; heifers treated with a single dose of relaxin ( $\mathrm{N}=7$; Group 1R, $3000 \mathrm{U} / \mathrm{mg}$ in $2 \mathrm{ml} \mathrm{PBS})$; and animals treated twice with relaxin $(\mathrm{N}=7$; Group 2R; $3000 \mathrm{U} / \mathrm{mg} \times 2$, given $12 \mathrm{~h}$ apart in $2 \mathrm{ml}$ PBS). Relaxin was extracted from ovaries of pregnant pigs and purified $(3000 \mathrm{U} / \mathrm{mg}$ ) according to procedures described previously (Büllesbach \& Schwabe, 1985). The animals were bled by venepuncture once daily beginning on Day 272 or 273 of gestation, and the treatments were given on Day 276 or 277 (averaged Day 276.5 for each group), 4 or 5 days before expected parturition. The external jugular vein was fitted with an indwelling catheter (i.d. $0.125 \mathrm{~cm}$, o.d. 0.225 cm; Tygon Microbore Tubing, No. 14-170 SE, Fisher Scientific Co., Pittsburg, PA, USA) on Day 275 for sequential blood sampling for $27 \mathrm{~h}(3 \mathrm{~h}$ pretreatment and $24 \mathrm{~h}$ after treatment) at 15 -min intervals on the day of hormone or placebo treatments. The catheter was flushed with heparinized $(100 \mathrm{U} / \mathrm{ml})$ PBS after each blood sample was withdrawn. The blood samples, $10 \mathrm{ml}$ for each sequential and daily bleeding, were collected in culture tubes with heparin, maintained on ice and centrifuged at $2000 \mathrm{~g}$ for $10 \mathrm{~min}$. Plasma was removed into two siliconized $12 \times 75 \mathrm{~mm}$ culture tubes, frozen, and stored at $-20^{\circ} \mathrm{C}$ for radioimmunoassay for progesterone and relaxin.

Measurements of cervical dilatation and pelvic area. The cervical diameter and pelvic area were measured twice daily from the day the experiment started to the day after parturition. The recorded unit is $\mathrm{cm}$ for the cervical dilatation and $\mathrm{cm}^{2}$ for the pelvic area. Dilatation of the cervix was measured intravaginally by using a specially designed stainless-steel probe (Perezgrovas \& Anderson, 1982; Musah et al., 1986a, b). Pelvic area was calculated from the determination of pelvic height and width by using a pelvimeter (Lane Manufacturing, Inc., Denver, CO, USA). Pelvic height was measured by the linear distance from the approximate midpoint of the dorsal surface of the symphysis pubis to the ventral surface of the prominent junction of the 3rd and 4th sacral vertebrae (Rice \& Wiltbank, 1972; Perezgrovas \& Anderson, 1982; Musah et al., 1986a, b). The pelvic width was measured by the greatest distance between the depression point in the bodies of the ilia at right angles to vertical measurements. The area was obtained by multiplying the height and width of the pelvis. Dystocia score was as follows: $0=$ unknown; 1 = unassisted, anterior presentation with two front legs; $2=$ hand pull, anterior presentation with two front legs; 3 = hand pull, anterior presentation with one leg back; $4=$ hand pull, posterior presentation; $5=$ chain-jack pull; $6=$ Cesarean section; $7=$ fetectomy. The percentage value indicates the proportion of animals that required assistance. The duration of gestation, time of delivery, the dystocia score, and percentage of animals requiring assistance, and the sex and body weight of calf were recorded. The interval from first relaxin or PBS treatment to parturition was calculated to determine the effect of relaxin on parturition.

Radioimmunoassay of progesterone. Peripheral plasma concentrations of progesterone were determined in duplicate $200-\mu l$ samples by the procedure described by Musah et al. (1986b), using the same fully characterized antibody (GDN-337) (Niswender, 1973; Gibori et al., 1977). The accuracy and precision of the assay were determined by 
adding known amounts of standard progesterone to $200 \mu \mathrm{l}$ plasma from an ovariectomized cow in standard samples of $0.0,0.5,1 \cdot 25,5 \cdot 0,12.5,25 \cdot 0$ and $5.0 \mathrm{ng} / \mathrm{ml}$ in quadruplicate aliquants. These standard samples were assayed, blank values were subtracted, and the concentration of progesterone was averaged ( \pm s.e.): $0 \cdot 0,0.48 \pm 0.03,1.27 \pm 0.02$, $5 \cdot 5 \pm 0.28,13 \cdot 6 \pm 0.32,25.4 \pm 0.28$ and $5.6 \pm 0.41 \mathrm{ng} / \mathrm{ml}$, respectively. The sensitivity of the radioimmunoassay was $0.25 \mathrm{ng} / \mathrm{ml}$. The non-specific binding for all assays was $3.4 \%(n=21)$, and maximal antibody binding was $33 \cdot 6 \%$ $(n=21)$. The overall extraction efficiency was $87.2 \%(n=21)$ and the inter- and intra-assay coefficients of variation were $8.1 \%(n=18)$ and $7.8 \%(n=6)$, respectively.

Radioimmunoassay of relaxin. Relaxin in bovine peripheral blood plasma was quantified in duplicate aliquants of 25-200 $\mu$ l by using an homologous double-antibody radioimmunoassay for pig relaxin as described by O'Byrne \& Steinetz (1976) and modified and validated by Musah et al. (1986b, 1987a, b, 1990b). The sensitivity of the assay was $30 \mathrm{pg} /$ tube. The accuracy and precision of the assay were quantified by adding known amounts of standard pig relaxin to $200 \mu \mathrm{l}$ plasma from an ovariectomized cow in standard samples of $0 \cdot 125,0 \cdot 25,0 \cdot 50,2 \cdot 50,7 \cdot 50,10 \cdot 0,12 \cdot 5,15 \cdot 0,20 \cdot 0$ and $25.0 \mathrm{ng} / \mathrm{ml}$ in quadruplicate aliquants. The plasma blank values were assayed and the values were subtracted from those tubes containing known amounts of relaxin. The concentration of relaxin averaged ( \pm s.e.) $0.14 \pm 0.011$, $0.26 \pm 0.020,0.58 \pm 0.228,3 \cdot 12 \pm 0.053,8.12 \pm 0.435,10.8 \pm 0.335,12.9 \pm 0.363,14.4 \pm 0.557,20 \cdot 1 \pm 0.585$, and $25.0 \pm 0.366 \mathrm{ng} / \mathrm{ml}$. The inter- and intra-assay coefficients of variation were $7.2 \%(n=4)$ and $8.6 \%(n=10)$, respectively. The non-specific binding of the assay was $2 \cdot 2 \%(n=6)$, and the maximal binding of the first antibody to standard relaxin was $32.9 \%(n=6)$, respectively.

Iodination of monotyrosylated relaxin with $1 \mathrm{mCi}{ }^{125}$ (IMS 30: Amersham Corp., Arlington Heights, IL, USA) was done by using the chloramine T procedure. Purified pig CM-B relaxin (3000 U/mg; Dr B. G. Steinetz, New York University Medical Center, Tuxedo, NY, USA) was used as the assay standard. Each tube received $100 \mu 1$ ${ }^{125}$ I-labelled monotyrosylated relaxin in PBS-1\% BSA (35 000 c.p.m.), was vortexed for $5 \mathrm{sec}$ and then incubated for $30 \mathrm{~min}$. Antiporcine relaxin serum [100 $\mu \mathrm{l}$; male rabbit $6(\mathrm{R} 6)$; from Dr Steinetz] in a 1:15000 dilution containing $0.05 \mathrm{M}$-ethylenediaminetetraacetic acid (EDTA)-PBS and $6 \%$ male rabbit serum was added to each tube and incubated at $4^{\circ} \mathrm{C}$ for $48 \mathrm{~h}$. Diluted goat-rabbit gamma-globulin ( $200 \mu \mathrm{l}$; lot no. 30635; Cappel, Organon Teknika, Westchester, PA, USA) in a 1:10 dilution containing 0.01 M-PBS was then added to each tube and incubated for $18-24 \mathrm{~h}$ at $4^{\circ} \mathrm{C}$. The samples were centrifuged $(1700 \mathrm{~g})$ for $30 \mathrm{~min}$, the supernatant was aspirated, and the precipitate was counted for $2 \mathrm{~min}$ in an automatic gamma-counter (Packard Cobra Auto Gamma 5003).

Statistical analysis of data. Experimental units in this study were the individual animals, which were assigned to treatments at random. The data were analysed by split-plot design by using the general linear model and Student's $t$ test for comparisons between treatment groups (Snedecor \& Cochran, 1980; Blair et al., 1979).

\section{Results}

\section{Facilitation of parturition}

Intramuscular injection of dairy heifers with purified pig relaxin once or twice ( $12 \mathrm{~h}$ apart) on Day 276.5 induced earlier calving $(P<0.05, P<0.01)$ than in the controls given PBS (Table 1). The dystocia scores were decreased by relaxin treatments, and the incidence of dystocia was decreased to $43 \%$ ( 3 of 7 ) and 29\% (2 of 7) for animals in Groups $1 \mathrm{R}$ and $2 \mathrm{R}$ compared with $57 \%$ (4 of 7) in Group C $(P<0.05)$. The ratios of male and female calves and the body weights of the calves remained similar $(P>0.05)$ among the three treatment groups (Table 1). There was no evidence that the placenta was retained beyond $24 \mathrm{~h}$ in any of the experimental and control animals.

\section{Peripheral plasma concentrations of relaxin}

As shown in Figs 1(a) and 2(a) and Table 2, pretreatment concentrations of relaxin remained similar $(P>0.05)$ among the three groups (Group C, $0.29 \pm 0.06 \mathrm{ng} / \mathrm{ml}$; Group 1R, 0.30 $\pm 0.04 \mathrm{ng} /$ $\mathrm{ml}$; Group $2 \mathrm{R}, 0.29 \pm 0.05 \mathrm{ng} / \mathrm{ml}$ ) and so these values were combined in Figs 1(a) and 2(a). Relaxin values in Group $C$ heifers remained unchanged from the pretreatment means throughout $24 \mathrm{~h}$ of sequential blood sampling and to subsequent parturition. In Groups $1 R$ and $2 R$, relaxin concentrations were markedly increased $(P<0.01)$ compared with Group C (Table 2). Relaxin reached peak levels of $19 \pm 2.2$ and $17 \pm 2.6 \mathrm{ng} / \mathrm{ml} 1 \mathrm{~h}$ after the first i.m. injection of the hormone in both groups (Figs 1a \& 2a). A similar peak of relaxin occurred after the second hormone injection $12 \mathrm{~h}$ later (Fig. 2a). Circulating relaxin returned to basal levels within $48 \mathrm{~h}$ after the first relaxin treatment in Group 1R (Fig. 1a). 
Table 1. Effect of relaxin $(3000 \mathrm{U} / \mathrm{mg}$, i.m.) on pregnancy and parturition in dairy heifers

\begin{tabular}{|c|c|c|c|c|c|c|c|c|}
\hline \multirow[b]{2}{*}{ Group } & \multirow{2}{*}{$\begin{array}{l}\text { No. of } \\
\text { heifers }\end{array}$} & \multirow{2}{*}{$\begin{array}{l}\text { Duration of } \\
\text { pregnancy } \\
\text { (days) }\end{array}$} & \multirow{2}{*}{$\begin{array}{l}\text { Interval from } \\
\text { first treatment } \\
\text { to calving }(\mathrm{h})\end{array}$} & \multicolumn{2}{|c|}{ Dystocia } & \multirow{2}{*}{$\begin{array}{c}\text { Calf } \\
\text { body wt } \\
(\mathrm{kg})\end{array}$} & \multicolumn{2}{|c|}{ Sex of calf } \\
\hline & & & & Score & $\%$ & & Female & Male \\
\hline $\mathrm{C}$ & 7 & $282 \pm 1 \cdot 3$ & $125 \pm 34$ & 2.00 & 57 & $45 \pm 1.9$ & 4 & 3 \\
\hline $1 R$ & 7 & $280 \pm 0.8^{*}$ & $80 \pm 19^{*}$ & $1.43^{* *}$ & $43^{*}$ & $46 \pm 1 \cdot 4$ & 3 & 4 \\
\hline $2 \mathrm{R}$ & 7 & $279 \pm 0.8^{* *}$ & $64 \pm 17^{* *}$ & $1 \cdot 28^{* *}$ & $29 * *$ & $44 \pm 2 \cdot 0$ & 3 & 4 \\
\hline
\end{tabular}

Values are mean \pm s.e.m.

Dystocia score: $0=$ unknown; $1=$ unassisted, anterior presentation with two front legs; $2=$ hand pull, anterior presentation with two front legs; $3=$ hand pull, anterior presentation with one leg back; $4=$ hand pull, posterior presentation; $5=$ chain-jack pull; $6=$ Caesarean section; $7=$ fetectomy. The percentage value indicates the proportion of animals that required assistance.

${ }^{*} P<0.05$ compared with Group $\mathrm{C}$.

${ }^{* *} P<0.01$ compared with Group C.

Table 2. Effect of relaxin ( $3000 \mathrm{U} / \mathrm{mg}$, i.m.) on peripheral plasma relaxin and progesterone concentrations in late pregnant dairy heifers

\begin{tabular}{|c|c|c|c|c|c|}
\hline \multirow[b]{2}{*}{ Group } & \multirow{2}{*}{$\begin{array}{l}\text { No. of } \\
\text { heifers }\end{array}$} & \multicolumn{2}{|c|}{ Relaxin (ng/ml) } & \multicolumn{2}{|c|}{ Progesterone $(\mathrm{ng} / \mathrm{ml})$} \\
\hline & & Pretreatment & Post-treatment & Pretreatment & Post-treatment \\
\hline 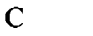 & 7 & $0 \cdot 3 \pm 0.06$ & $0 \cdot 3 \pm 0.08$ & $6 \cdot 1 \pm 0 \cdot 28$ & $6 \cdot 0 \pm 0 \cdot 13$ \\
\hline $1 \mathbf{R}$ & 7 & $0.3 \pm 0.04$ & $7 \cdot 1 \pm 0.89^{* *}$ & $6 \cdot 1 \pm 0.28$ & $4 \cdot 9 \pm 0 \cdot 11^{*}$ \\
\hline $2 \mathrm{R}$ & 7 & $0 \cdot 3 \pm 0.05$ & $11 \cdot 1 \pm 0.52^{* *}$ & $6.2 \pm 0.23$ & $4 \cdot 0 \pm 0 \cdot 10^{* *}$ \\
\hline
\end{tabular}

Values are mean \pm s.e.m.

${ }^{*} P<0.05$ compared with Group C.

${ }^{* *} P<0.01$ compared with Group $C$.

\section{Peripheral plasma concentrations of progesterone}

As shown in Figs 1(b) and 2(b) and Table 2, during the pretreatment period, progesterone averaged $6 \cdot 1 \pm 0 \cdot 26 \mathrm{ng} / \mathrm{ml}( \pm$ s.e.) in all 21 heifers. The post-treatment mean concentrations of progesterone were significantly decreased in Group $1 \mathrm{R}(P<0.05)$ and Group $2 \mathrm{R}(P<0.01)$ heifers compared with Group $C$ or with the pretreatment period within group (Table 2). Progesterone concentrations remained similar $(P>0.05)$ before and after treatment until 2 days before parturition in the PBS-treated controls (Table 2, Figs 1b \& 2b).

Figures 1(b) and 2(b) clearly indicate that progesterone concentrations in the peripheral blood began to decrease within $6 \mathrm{~h}$ after the first relaxin injection. The second injection in the Group $2 \mathrm{R}$ caused a further decrease $(P<0.01)$ in circulating progesterone. At $24 \mathrm{~h}$ after relaxin or PBS injection, plasma progesterone decreased to $2.7 \pm 1.1 \mathrm{ng} / \mathrm{ml}$ in Group $2 \mathrm{R}(P<0.01)$ and $3.5 \pm 0.9 \mathrm{ng} / \mathrm{ml}$ in Group 1R $(P<0.01)$ heifers compared with $6.0 \pm 0.1 \mathrm{ng} / \mathrm{ml}$ for Group $\mathrm{C}$ animals.

\section{Cervical diameter and pelvic area}

Dilatation of the uterine cervix was similar $(P>0.05)$ before hormone or placebo treatments among groups and differed $(P<0.01)$ after relaxin and PBS treatment in all three groups (Table 3; Figs $3 \mathrm{a} \& 4 \mathrm{a}$ ). Cervical dilatation was increased $109 \%$ and $76 \%$ at $48 \mathrm{~h}$ after injections in Group $2 \mathrm{R}$ $(P<0.01)$ and Group $1 \mathrm{R}(P<0.05)$ groups, compared with $53 \%$ in Group C (Figs $3 \mathrm{a} \& 4 \mathrm{a})$.

In these late pregnant heifers, the enlarged pelvic area was similar $(P>0.05)$ before relaxin or PBS treatment, but differed $(P<0.05)$ after hormone treatments (Table 3; Figs 3b \& 4b). The 

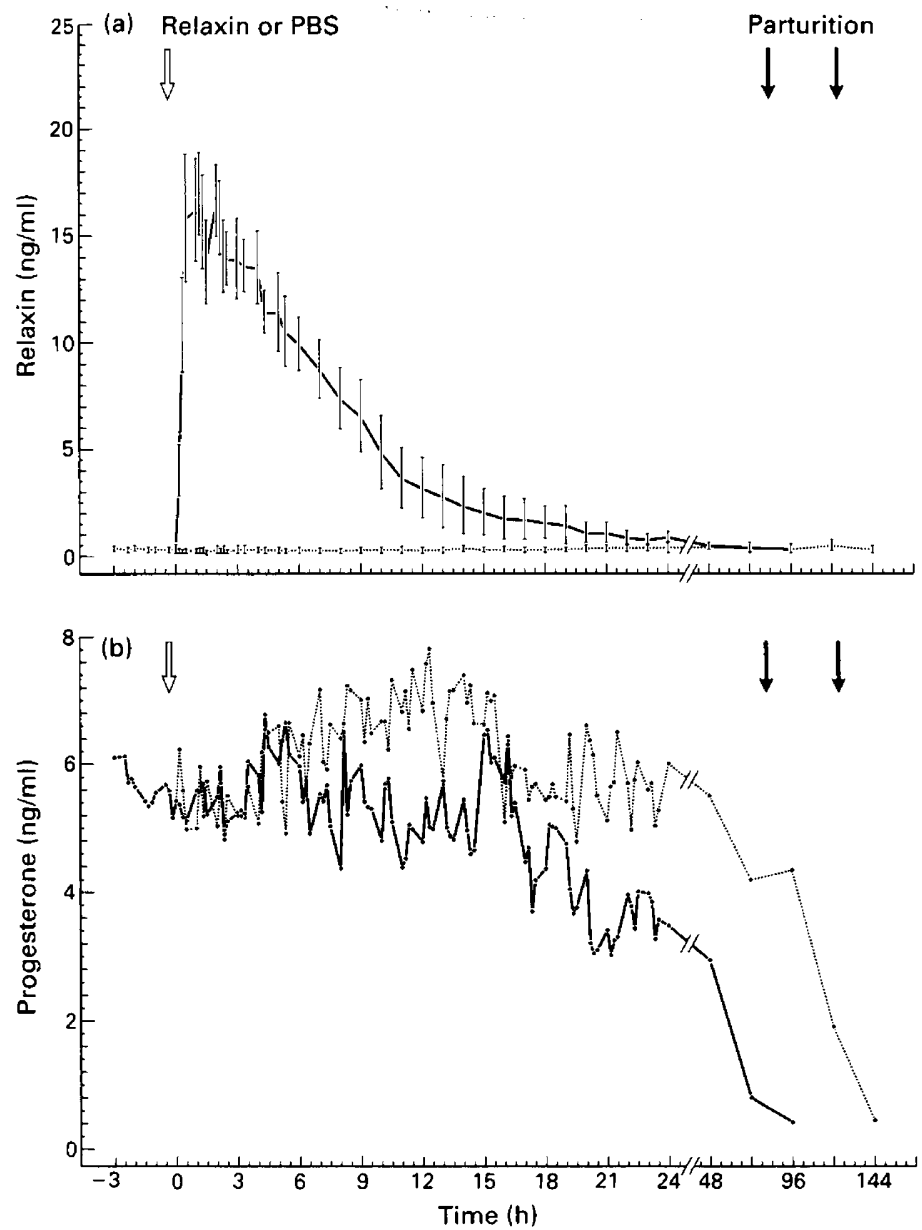

Fig. 1. Mean ( \pm s.e.m.) relaxin (a) and mean progesterone (b) concentrations in peripheral plasma after one i.m. injection of purified pig relaxin $(3000 \mathrm{U} / \mathrm{mg}$ in $2 \mathrm{ml} \mathrm{PBS}$; Group 1R) or phosphate-buffered saline (PBS, $2 \mathrm{ml}$; Group C) in relation to time after beginning of treatments at 08:00 h (time 0) on Day 276 or 277 (averaged Day 276.5 for each group) of gestation in late pregnant Holstein heifers. $\mathrm{N}=7$ in each group, progesterone pooled s.e.m. $=0 \cdot 10$.

comparisons of pretreatment means with the post-treatment means and the expansion of pelvic area were greater $(P<0.05)$ during the post-treatment periods than those of the pretreatment periods in all groups. Although the pelvic area post-treatment means in Groups $1 R$ and $2 R$ were greater, they did not differ significantly from those of Group $C$ (Table 3 ). The time course of the pelvic area growth, however, was increased in Groups $1 R$ and $2 R$ by $24 \mathrm{~h}$ after treatment, whereas the enlargement of the pelvic area in Group $C$ remained less throughout pregnancy and increased markedly only within 2 days preceding parturition (Figs $3 b \& 4$ b). Pelvic area was increased $26 \%$, $22 \%$ and $14 \%$ at $48 \mathrm{~h}$ after i.m. injections in Groups $2 \mathrm{R}, 1 \mathrm{R}$ and $\mathrm{C}$, respectively. Overall cervical and pelvic development was similar among groups at the time of parturition in relaxin- and placebo-treated heifers.

\section{Discussion}

Relaxin in dairy heifers caused an immediate transient decrease in the circulating concentrations of progesterone, and accelerated the decrease of the plasma progesterone concentrations preceding 


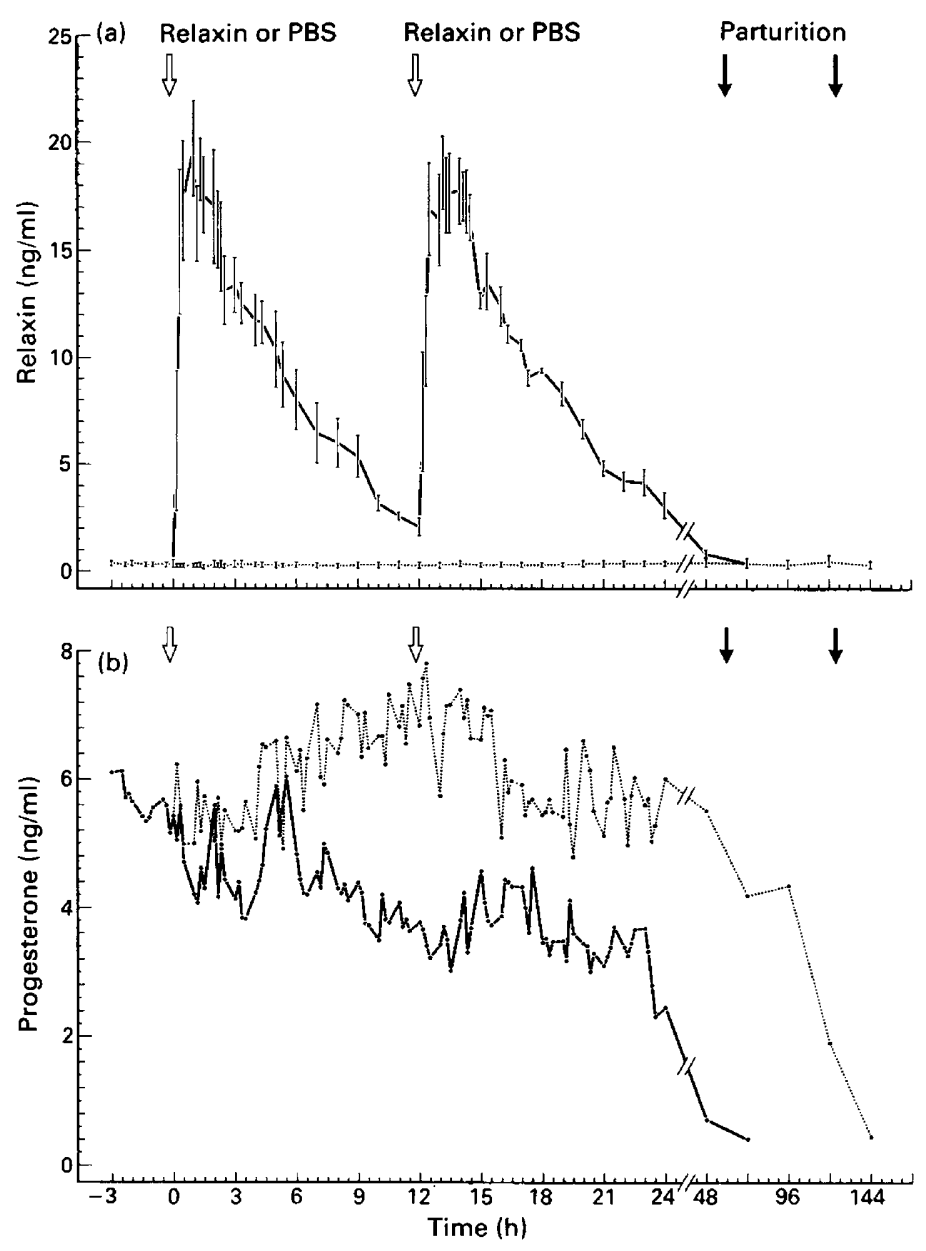

Fig. 2. Mean ( \pm s.e.m.) relaxin (a) and mean progesterone (b) concentrations in peripheral plasma after $2 \mathrm{i} . \mathrm{m}$. injections of purified pig relaxin $(2 \times 3000 \mathrm{U} / \mathrm{mg}$, given $12 \mathrm{~h}$ apart in $2 \mathrm{ml}$ PBS; Group 2R) or phosphate-buffered saline (PBS, $2 \mathrm{ml}$; Group C) in relation to time after beginning of treatments at 08:00 h (time 0) on Day 276 or 277 (averaged Day 276.5 for each group) of gestation in late pregnant Holstein heifers. $\mathbf{N}=7$ in each group, progesterone pooled s.e.m. $=0 \cdot 11$.

Table 3. Effect of relaxin ( $3000 \mathrm{U} / \mathrm{mg}$, i.m.) on cervical dilatation and pelvic area in late pregnant dairy heifers

\begin{tabular}{|c|c|c|c|c|c|}
\hline \multirow[b]{2}{*}{ Group } & \multirow{2}{*}{$\begin{array}{l}\text { No. of } \\
\text { heifers }\end{array}$} & \multicolumn{2}{|c|}{ Cervical dilatation $(\mathrm{cm})$} & \multicolumn{2}{|c|}{ Pelvic area $\left(\mathrm{cm}^{2}\right)$} \\
\hline & & Pretreatment & Post-treatment & Pretreatment & Post-treatment \\
\hline $\begin{array}{l}C \\
1 R \\
2 R\end{array}$ & $\begin{array}{l}7 \\
7 \\
7\end{array}$ & $\begin{array}{l}4.8 \pm 0.19 \\
4.9 \pm 0.22 \\
5.1 \pm 0.19\end{array}$ & $\begin{array}{r}8.5 \pm 0.20^{* *} \\
9.8 \pm 0.21^{* *} \\
10.4 \pm 0.24^{* *}\end{array}$ & $\begin{array}{l}276 \pm 10 \\
268 \pm 8 \\
279 \pm 8\end{array}$ & $\begin{array}{l}338 \pm 33^{*} \\
341 \pm 29^{*} \\
349 \pm 28^{*}\end{array}$ \\
\hline
\end{tabular}

Values are mean \pm s.e.m.

* $P<0.05$ compared within group with pretreatment mean.

${ }^{* *} P<0.01$ compared within group with pretreatment mean. 

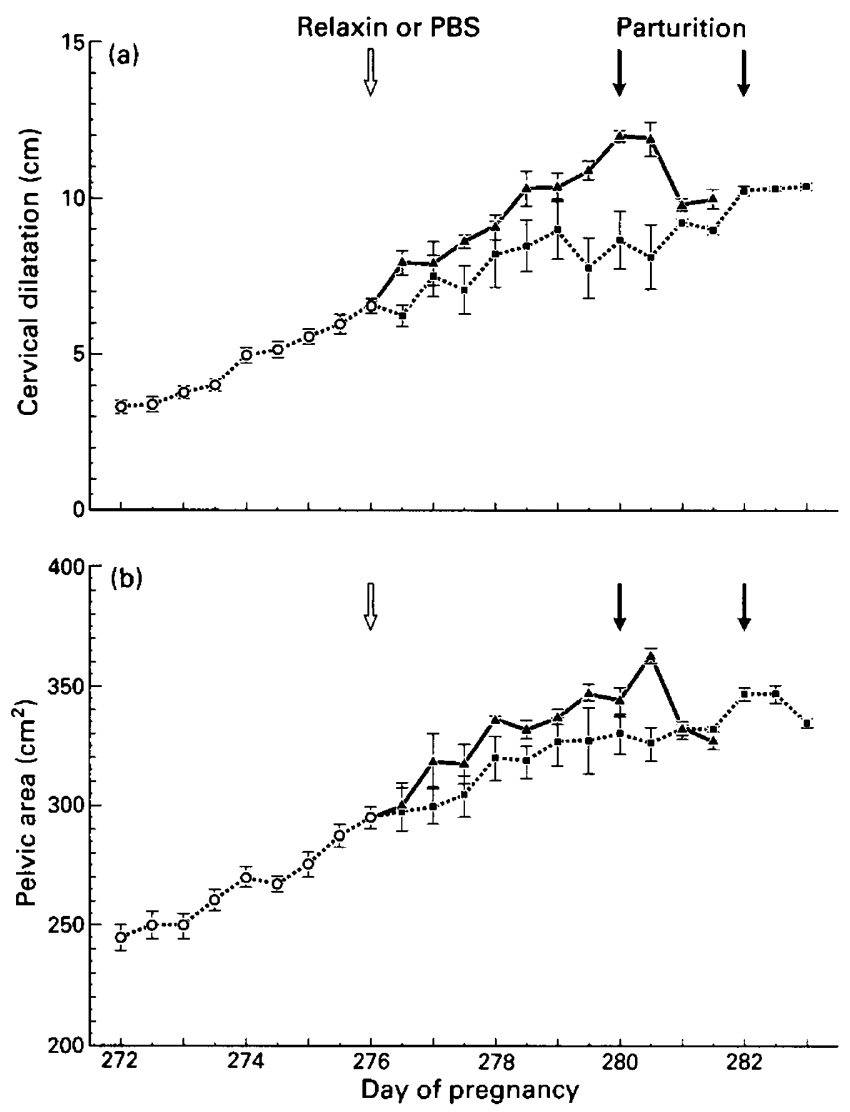

Fig. 3. Mean ( \pm s.e.m.) cervical dilatation (a) and pelvic area (b) after 1 i.m. injection of purified pig relaxin ( $3000 \mathrm{U} / \mathrm{mg}$ in $2 \mathrm{ml}$ PBS; Group 1R) or phosphate-buffered saline (PBS, $2 \mathrm{ml}$; Group C) in relation to day after beginning of treatments at $08: 00 \mathrm{~h}$ on Day 276 or 277 (averaged Day 276.5 for each group) of gestation in late pregnant Holstein heifers. $N=7$ in each group.

the onset of parturition. This study revealed that the second injection of relaxin $12 \mathrm{~h}$ after the first hormone treatment caused a further decrease in circulating progesterone concentrations, which remained at this reduced concentration until parturition. The results in this study indicated that relaxin injected i.m. once or twice, $12 \mathrm{~h}$ apart, in late pregnant dairy heifers facilitated parturition by reducing the interval to calving. Earlier calving was associated with increased cervical dilatation and pelvic area expansion, as well as a decreased incidence of dystocia compared with controls treated with placebo. These results were consistent with earlier findings that $6000 \mathrm{U}$ relaxin given i.m. once on Day 275 (Musah et al., 1989b), or relaxin combined with a PGF-2 $\alpha$ analogue (cloprostenol) or a glucocorticoid (dexamethasone) (Musah et $a l ., 1986 \mathrm{a}, \mathrm{b})$ on Day 273 caused earlier calving compared with PBS-treated beef heifers. In contrast with these results, the continuous i.v. infusion of relaxin in late pregnant beef heifers did not induce earlier or prolonged parturition, but did decrease progesterone secretion (Smith, 1989).

The peak peripheral blood concentrations of exogenous relaxin in the heifers in this study occurred $1 \mathrm{~h}$ after relaxin treatment and decreased gradually during $6 \mathrm{~h}$. A similar pattern of decreasing relaxin plasma concentrations was found after the second hormone injection $12 \mathrm{~h}$ later. 

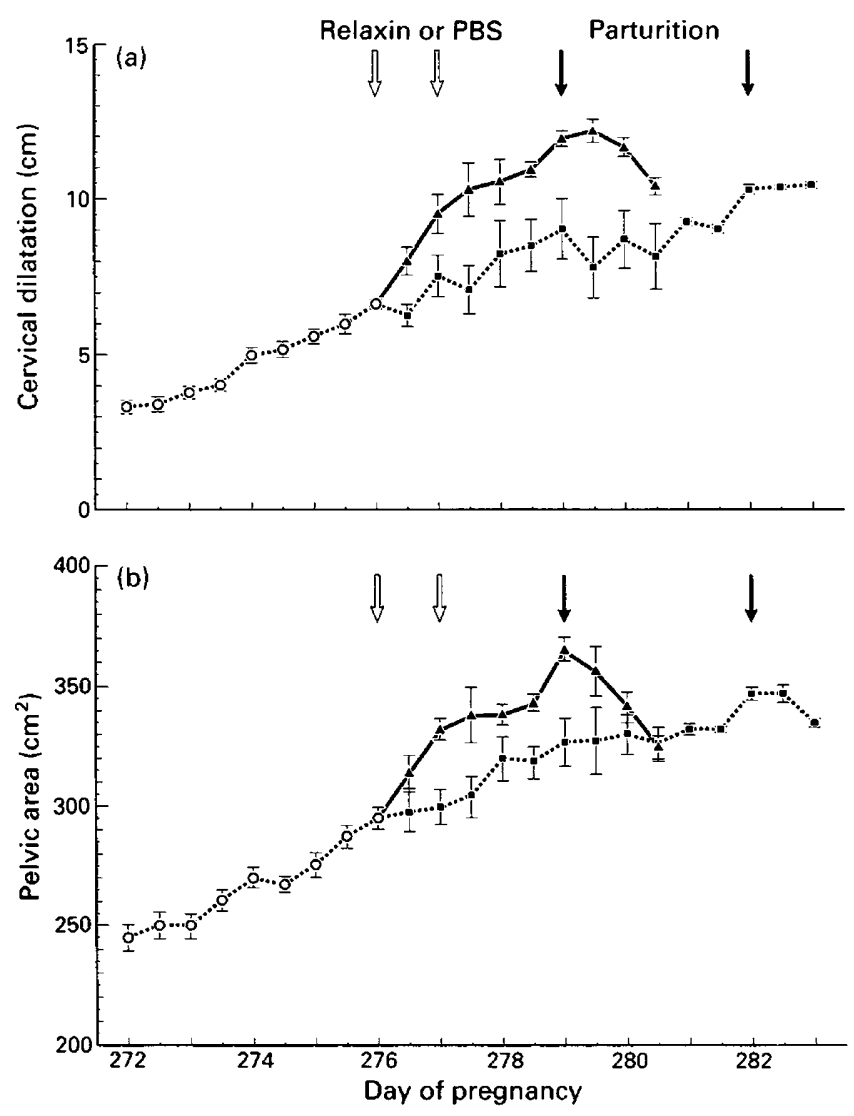

Fig. 4. Mean ( \pm s.e.m.) cervical dilatation (a) and pelvic area (b) after $2 \mathrm{i} . \mathrm{m}$. injections of purified pig relaxin $(2 \times 3000 \mathrm{U} / \mathrm{mg}$, given $12 \mathrm{~h}$ apart in $2 \mathrm{ml} \mathrm{PBS}$; Group 2R) or phosphatebuffered saline (PBS, $2 \mathrm{ml}$; Group C) in relation to day after beginning of treatments at 08:00 $\mathrm{h}$ on Day 276 or 277 (averaged Day 276.5 for each group) of gestation in late pregnant Holstein heifers. $\mathrm{N}=7$ in each group.

These findings in dairy heifers were consistent with earlier reports for beef cattle (Musah et al., 1987b, 1989b). Continuous i.v. infusion of increasing dosages of pig relaxin during a period of $216 \mathrm{~h}$ in late pregnant beef heifers resulted in a steady stepwise increase in circulating relaxin from 1 to $115 \mathrm{ng} / \mathrm{ml}$ (Smith, 1989). The smaller hormone infusion dosages were less effective than the greater dosages of relaxin in decreasing circulating progesterone values.

The mechanism by which relaxin mediates luteolysis in cattle is unknown. This and earlier studies confirm that dose and time of relaxin administration are important in determining whether complete luteal demise and parturition or temporarily suppressed luteal progesterone secretion without parturition would occur in cattle (Musah et al., 1986a, b, 1987b). From several studies, it has been postulated that regression of the bovine corpus luteum results from the feedback interaction of PGF-2 $\alpha$, oxytocin, and relaxin (Hansel \& Dowd, 1985; Musah et al., 1990a, b). PGF-2 $\alpha$ can cause oxytocin secretion from bovine corpora lutea in vitro (Abdelgadir et al., 1987; Flint \& Sheldrick, 1986). These feedback interactions of PGF-2 $\alpha$ and oxytocin lead to a decrease in progesterone secretion; substrates available for the synthesis of oestradiol-17 $\beta$ (Flint $\&$ Sheldrick, 1986) and oxytocin promote the luteal PGF-2 $\alpha$ receptors (Niswender et al., 1985). In the cow, PGF- $2 \alpha$ inhibits LH- or cAMP-stimulated progesterone synthesis in large luteal cells and 
stimulates progesterone synthesis in small cells (Alila et al., 1988). The bovine corpora lutea produce relatively large amounts of all the prostanoids, including PGF-2 $\alpha$ (Hansel \& Dowd, 1985). Relaxin given by i.m. injection has been shown to induce PGF- $2 \alpha$ release, with a decrease in progesterone secretion (Nara \& First, 1981; Musah et al., 1989b) and a spike release of plasma oxytocin in cattle (Musah et al., 1989b). The release of oxytocin by bovine luteal cells in culture is dose-dependent (Musah et al., 1990a). In addition, i.m. application of relaxin also increased the oestrone and oestradiol-17 $\beta$ concentrations in late pregnant beef cattle (Musah et al., 1986b). These results suggested that luteolysis in cattle may be mediated by oxytocin, which induces PGF- $2 \alpha$ receptors, and (or) by relaxin, which increases PGF- $2 \alpha$ production but inhibits in-vitro oxytocin release from the corpora lutea. Relaxin is most probably luteolytic in cattle in as much as its application can increase circulating PGF-2 $\alpha$, oxytocin and oestrogen concentrations, and reduce progesterone. Subsequently, it facilitates parturition by remodelling the cervical collagen and pelvic symphysial ligaments to enlarge the birth canal.

Pelvic canal expansion results from an increase in both the rate of linear growth as well as an absolute increase in pelvic height and width (Musah et al., 1986b). This increase in pelvic height and width may be the result of relaxation of sacroiliac ligaments (Fields et al., 1981); formation of interpubic ligaments (Leitch et al., 1959); and modification of pubic symphysis, by transforming symphysial cartilage and bone (Rice, 1969). Relaxin induces the release of the lysosomal cystine protease and exopeptidase (McDonald \& Schwabe, 1982) that cause the degradation of the cartilage.

The mechanism by which relaxin promotes cervical dilatation remains poorly understood. Several studies have indicated that relaxin acts directly on cervical tissue: finite numbers of high-affinity sites for radioiodinated pig relaxin in cervical tissue of the pig were reported (Mercado-Simmen et al., 1982); amounts of the cAMP increased in human cervical tissue after in-vitro incubation with pig relaxin (Norstrom \& Wiqvist, 1985); and purified pig relaxin inhibited ${ }^{3} \mathrm{H}$-proline incorporation into human cervical tissue during in-vitro incubation (Wiqvist et al., 1984). These findings suggest that relaxin receptors are available in cervical tissue and that the action of relaxin may be mediated through cAMP-dependent protein kinase. At the end of pregnancy, the disruptions of the collagen framework and cervical matrix are processes resulting from changes in collagen metabolism and an increase in hyaluronic acid and water content. The flexibility and distensibility of the cervix result from breakdown and loss of collagen and dermatin/ chondroitin sulphate (Huszer, 1981). Relaxin acts on the collagen of the cervix and pelvis and causes relaxation by inducing the disintegration of the collagen matrix (Schwabe et al., 1978; Porter, 1979). Downing \& Sherwood (1986) observed changes in collagen and proteoglycan concentrations of cervical tissue after relaxin treatment; these observations may reflect changes in the solubility and content of collagen in the cervix before parturition. The results in the present study were interpreted to indicate that relaxin promotes cervical dilatation, probably by remodelling collagen in late pregnant cattle.

We thank Dr D. K. Hotchkiss (Department of Statistics) for assistance $\mathrm{w}$. A. I. Musah, C. J. Huang, Y. Li, K. E. Langner, and M. Shipka for technical assistance; Dr M. D. Kenealy for animals used in this study; Dr P. G. Eness for monitoring the health of animals; Dr G. D. Niswender (Department of Physiology and Biophysics, Colorado State University, Fort Collins) for the progesterone antiserum; and Dr B. G. Steinetz (New York University Medical Center, Laboratory for Experimental Medicine and Surgery in Primates, Tuxedo) for the relaxin antiserum.

This study was supported in part by US Department of Agriculture, ARS, CSRS, OGPS Competitive Grants 86-CRCR-1-2130 and 88-37242-3918. This is Journal Paper J-14097 of the Iowa Agriculture and Home Economics Experiment Station, Ames, IA. Projects 2443, 2444, 2797, 2896, and 2273, the last a contributing project to North Central Regional Research Project NC-113. 


\section{References}

Abdelgadir, S.E., Swanson, L.V., Oldfield, J.E. \& Stormshak, F. (1987) Prostaglandin $\mathrm{F}_{2} \alpha$-induced release of oxytocin from bovine corpora lutea in vitro. Biol. Reprod. 37, 550-555.

Alila, H.W., Dowd, J.P., Corradino, R.A., Harris, W.V. \& Hansel, W. (1988) Control of progesterone production in small and large bovine luteal cells separated by flow cytometry. $J$. Reprod. Fert. 82, 645-655.

Anderson, L.L. (1987) Regulation of relaxin secretion and its role in pregnancy. $A d v$. exp. Med. Biol. 219, $421-463$.

Anderson, L.L., Ford, J.J., Melampy, R.M. \& Cox, D.F. (1973) Relaxin in porcine corpora lutea during pregnancy and after hysterectomy. Am. J. Physiol. 225, 1215-1219.

Anderson, L.L.s Perezgrovas, R., O'Byrne, E.M. \& Steinetz, B.G. (1982) Biological actions of relaxin in pigs and beef cattle. Ann. New York Acad. Sci. 380, $131-150$.

Bagna, B., Schwabe, C. \& Anderson, L.L. (1990) Relaxin on facilitation of parturition in Holstein heifers. $J$. Anim. Sci. 68 (Suppl. 1), 449, Abstr. 522.

Blair, W.H., Goodnight, J.H., Helwig, J.T. \& Council, K.A. (1979) SAS User's Guide, pp. 121-130, SAS Inst., Inc., Cary, NC.

Büllesbach, E.E. \& Schwabe, C. (1985) Naturally occurring porcine relaxin and large-scale preparation of the B29 hormone. Biochemistry, $N Y 24,7717-7222$.

Downing, S.J. \& Sherwood, O.D. (1986) The physiological role of relaxin in the pregnant rat: the influence of relaxin on cervical collagen and glycosaminoglycans. Endocrinology 118, 471-479.

Evans, G., Wathes, D.C., King, G.J., Armstrong, D.T. \& Porter, D.G. (1983) Changes in relaxin production by the theca during the preovulatory period of the pig. J. Reprod. Fert. 69, 677-683.

Felder, K.J., Molina, J.R., Benoit, A.M. \& Anderson, L.L. (1986) Precise timing for peak relaxin and decreased progesterone secretion after hysterectomy in the pig. Endocrinology 119, 1502-1509.

Fields, M.J., Fields, P.A., Castro-Hernandez, A. \& Larkin, L.H. (1980) Evidence for relaxin in corpora lutea of late pregnant cows. Endocrinology 107, 869-876.

Fields, M.J., Roberts, R. \& Castro-Hernandez, A. (1981) Two cow relaxins: A comparison. In Relaxin, pp. 119-125. Eds G. D. Bryant-Greenwood, H. D. Niall \& F. C. Greenwood. Elsevier/North-Holland, New York.

Flint, A.P.F. \& Sheldrick, E.L. (1986) Ovarian oxytocin and the maternal recognition of pregnancy. J. Reprod. Fert. 76, 831-839

Gibori, G., Antazak, E. \& Rothchild, I. (1977) The role of estrogen in the regulation of luteal progesterone secretion in the rat after day 12 of pregnancy. Endocrinology 100, 1483-1495.

Hansel, W. \& Dowd, J.P. (1985) New concepts of the control of corpus luteum function. $J$. Reprod. Fert. 78, 755-768.

Huszer, G. (1981) Biology and biochemistry of myometrial contractility and cervical motivation. Semin. Perineonatology 5, 216.
Leitch, R.K., Hytten, F.E. \& Billewecz, W.Z. (1959) Maternal and neonatal weights of some mammalia. Proc. Zool. Soc., Lond. 113, 11-28.

Li, Y., Molina, J.R., Klindt, J., Bolt, D.J. \& Anderson, L.L. (1989) Prolactin maintains relaxin and progesterone secretion by aging corpora lutea after hypophysial stalk transection or hypophysectomy in the pig. Endocrinology 124, 1294-1304.

MacLennan, A.H., Green, R.C., Bryant-Greenwood, G.D., Greenwood, F.C. \& Seamark, R.F. (1980) Ripening of human cervix and induction of labour with purified porcine relaxin. Lancet I, 220-223.

McDonald, J.K. \& Schwabe, C. (1982) Relaxin-induced elevation of cathepsin B and dipeptidyle peptidase I in the mouse pubic symphysis, with localization by fluorescence enzyme histochemistry. Ann. New York Acad. Sci. 380, 178-186.

Mercado-Simmen, R.C., Goodwin, B., Ueno, M.S., Yamamoto, S.Y. \& Bryant-Greenwood, G.D. (1982) Relaxin receptors in the myometrium and cervix of the pig. Biol. Reprod. 26, 120-128.

Musah, A.I., Schwabe, C., Willham, R.L. \& Anderson, L.L. (1986a) Pelvic development as affected by relaxin in three genetically selected frame sizes of beef heifers. Biol. Reprod. 34, 363-369.

Musah, A.I., Schwabe, C., Willham, R.L. \& Anderson, L.L. (1986b) Relaxin on induction of parturition in beef heifers. Endocrinology 118, 1476-1482.

Musah, A.I., Schwabe, C., Willham, R.L. \& Anderson, L.L. (1987a) Induction of parturition, progesterone secretion, and delivery of placenta in beef heifers given relaxin with cloprostenol or dexamethasone. Biol. Reprod. 37, 797-803.

Musah, A.I., Schwabe, C. \& Anderson, L.L. (1987b) Acute decrease in progesterone and increase in estrogen secretion caused by relaxin during late pregnancy in beef heifers. Endocrinology 120, 317-324.

Musah, A.I., Schwabe, C., Willham, R.L. \& Anderson, L.L. (1988) Dystocia, pelvic and cervical dilatation in beef heifers after induction of parturition with relaxin combined with cloprostenol or dexamethasone. Anim. Reprod. Sci. 16, 237-248.

Musah, A.I., Schwabe, C. \& Anderson, L.L. (1989a) Relaxin regulates oxytocin secretion in late pregnant beef heifers. Proc. Soc. exp. Biol. Med. 191, 124-129.

Musah, A.I., Huang, C.J., Bagna, B., Schwabe, C. \& Anderson, L.L. (1989b) Peripheral plasma progesterone, prostaglandin $F_{2} \alpha$, prostaglandin $E_{2}$, 6-keto prostaglandin, and calving after relaxin administration in heifers. Biol. Reprod. 40 (Suppl. 1), 70, Abstr. 69.

Musah, A.I., Schwabe, C. \& Anderson, L.L. (1990a) Relaxin and prostaglandin on oxytocin secretion from bovine luteal cells during different stages of gestation. Acta endocr., Copenh. 122, 396-402.

Musah, A.I., Schwabe, C. \& Anderson, L.L. (1990b) Relaxin, oxytocin and prostaglandin effects on progesterone secretion from bovine luteal cells during different stages of gestation. Proc. Soc. exp. Biol. Med. 195, 255-260.

Nara, B.S. \& First, N.L. (1981) Effect of indomethacin and prostaglandin $\mathrm{F}_{2} \alpha$ on parturition in swine. $J$. Anim. Sci. 52, 1360-1370. 
Niswender, G.D. (1973) Influence of the site of conjugation on the specificity of antibodies to progesterone. Steroids 22, 413-424.

Niswender, G.D., Schwale, R.H., Fitz, T.A., Farin, C.E. \& Sawyer, H.R. (1985) Regulation of luteal function in domestic ruminants: new concepts. Recent Prog. Horm. Res. 41, 101-151.

Norstrom, A. \& Wiqvist, I. (1985) Relaxin-induced changes in adenosine $3^{\prime}-5^{\prime}$ monophosphate levels in the human cervix. Acta endocr., Copenh. 109, 122-125.

O'Byrne, E.M. \& Steinetz, B.G. (1976) Radioimmunoassay of relaxin in sera of various species using an antiserum to porcine relaxin. Proc. Soc. exp. Biol. Med. 152, 272-276.

O'Byrne, E.M., Tabachnich, T., Anderson, L.L. \& Steinetz, B.G. (1989) Characterization of the circulating form of porcine relaxin: biological activity and terminal amino acids. Endocrinology 124, 2920-2927.

Perezgrovas, R. \& Anderson, L.L. (1982) Effect of porcine relaxin on cervical dilatation, pelvic area, and parturition in cattle. Biol. Reprod. 26, 756-776.

Porter, D.G. (1979) Relaxin: old hormone, new prospect. Oxford Rev. Reprod. Biol. 1, 1-57.

Porter, D.G. (1984) Relaxin: a multipurpose hormone. Excerpta Medica Int. Congr. Ser. 655, 522-526.

Rice, L.E. (1969) Dystocia in cattle. M.S. thesis, Colorado State University, Fort Collins.

Rice, L.E. \& Wiltbank, J.N. (1972) Factors affecting dystocia in beef cattle. J. Am. vet. med. Assoc. 161, 1348-1358.
Schwabe, C., McDonald, J.K. \& Steinetz, B.G. (1976) Primary structure of the A chain of porcine relaxin. Biochem. Biophys. Res. Commun. 70, 397-405.

Schwabe, C., McDonald, J.K. \& Steinetz, B.G. (1977) Primary structure of the B chain of porcine relaxin. Biochem. Biophys. Res. Commun. 75, 503-510.

Schwabe, C., Steinetz, B.G., Weiss, G., Segaloff, A., McDonald, J.K., O'Byrne, E.M., Hochmam, J., Carriere, B. \& Goldsmith, L. (1978) Relaxin. Recent Prog. Horm. Res. 34, 123-199.

Sherwood, O.D. (1988) Relaxin. In The Physiology of Reproduction, Vol. II, pp. 585-673. Eds E. Knobil \& J. Neill. Raven Press, New York.

Sherwood, O.D. \& O'Byrne, E.M. (1974) Purification and characterization of porcine relaxin. Archs Biochem. Biophys. 160, 185-196.

Smith, K.H. (1989) Continuous infusion of relaxin on preparturient blood hormone profiles and parturition in primiparous beef heifers, pp. 1-162. M.S. thesis, Iowa State University Library, Ames.

Snedecor, G.W. \& Cochran, W.G. (1980) Statistical Methods, 7 th edn. Iowa State University Press, Ames.

Wiqvist, I., Norstom, A., O'Byrne, E. \& Wiqvist, N. (1984) Regulatory influence of relaxin on human cervical and uterine connective tissue. Acta endocr., Copenh. 106, 127-132.

Received 7 July 1990 